\title{
PENDIDIKAN ISLAM MASA MAJAPAHIT \\ DAN DAKWAH SYEKH JUMADIL KUBRO \\ Isno
}

\author{
(Dosen STIT Raden Wijaya dan Staf Pengajar PAI SMAN 3 Kota \\ Mojokerto)
}

\section{Abstract}

The discussion of Syekh Jumadil Kubro figure cannot be denied from a long debate regarding its comprehensive history. Where he came from, how his life was, and where he buried in are still debatable. Beginning from the previously mentioned questions, it is interesting to discuss about a seminar within the event of 632nd annual commemoration of Syekh Jumadil Kubro which was conducted by Department of Tourism and Culture of Mojokerto District. The discussion by archeologist, historian, and ulamas ended up with a conclusion regarding the syekh figure. The figure was real. From mass conversion from Hinduism to Islam in Java, it was concluded that the syekh had a very effective missionary strategy so that the Hindus-Majapahit transformed into a Muslim society.

Keywords: Islamic Education, Majapahit and Syekh Jumadil Kubro.

\section{Abstrak}

Membahas sosok Syekh Jumadil Kubro, tidak lepas dari perdebatan panjang dalam menemukan sejarah utuh tentang asal usulnya. Dari manakah dia? Bagaimanakah kehidupannya? Di manakah dia bersemayam pada akhir hayatnya? Berpijak pada pertanyaan-pertanyaan tersebut, menjadi menarik ketika membahas sebuah sarasehan dalam peringatan haul ke 632 Syekh Jumadil Kubro yang diselenggarakan oleh Dinas Pariwisata dan kebudayaan Kabupaten Mojokerto. Dari sejumlah pakar, baik dari ahli arkeologi, sejarahwan maupun dari kalangan ulama yang diundang ada benang merah dalam menyepakati sosok Syekh Jumadil Kubro. Syekh Jumadil Kubro adalah tokoh nyata dan benar adanya dan bukan tokoh fiktif. Jika melihat konversi besar-besaran penduduk Jawa kepada Islam, maka sah untuk menyatakan kehebatan dan kelihaian 
Syekh Jumadil Kubro di dalam mengatur dakwah Islamnya. Bagaimana tidak, kekuatan Hindu-Majapahit yang begitu kokoh dengan didukung nama besar kerajaannya mampu "ditaklukan" dalam cengkraman aqidah Islam.

Kata Kunci: Pendidikan Islam, Majapahit, dan Syekh Jumadil Kubro

\section{A. Pendahuluan}

Membahas masalah Islamisasi, tidak bisa dilepaskan dari peran pendidikan di dalamnya. Karena antara Islamisasi dan pendidikan saling berkaitan erat. Untuk menyukseskan Islamisasi diperlukan pendidikan sebagai upaya penyebaran ide-ide Islam ke dalam nalar masyarakat. Islamisasi akan berhasil jika memperhatikan pendidikan masyarakat dengan baik. Islamisasi akan mendulang sukses jika pendidikannya ditata dengan apik, efektif sesuai dengan local genius masyarakat.

Bertolak dari dasar tersebut, penulis dalam tulisan ini hendak melacak jejak perjalanan Syekh Jumadil Kubro dalam mengembangkan Islamisasi di tanah Jawa khususnya dalam hal keterkaitannya dengan pendidikan yang dikembangkannya dalam masyarakat heterogen di Majapahit. Penulis berkeinginan untuk mencari model pendidikan yang ideal di Majapahit kemudian ditarik dalam ranah kekinian untuk dikembangkan dalam membangun masyarakat seperti kondisi masyarakat saat ini. Karena penulis berkeyakinan bahwa masyarakat Indonesia seperti kondisi saat ini tidak begitu jauh dengan kondisi Majapahit kala itu.

Lihat saja term-term yang dipakai pemimpin-pemimpin kita dari Soekarno sampai Soeharto hingga berlanjut pada zaman Susilo Bambang Yudhoyono bahkan Joko Widodo. Kata istana, nusantara, dan lain sebagainya. Strategi-strategi politik pun tidak bisa dilepaskan dari Majapahit. Bahkan wilayah Indonesia seperti saat ini konon juga merupakan peninggalan denah wilayah yang dikuasai Majapahit. Oleh karenanya mengetahui tentang konsep pendidikan Islam awal sebagaimana dikembangkan oleh Syekh Jumadil Kubro, menjadi sangat penting. 


\section{B. Pendidikan Islam dalam Ranah Sejarah}

Sejak awal perkembangan Islam, pendidikan mendapat prioritas utama masyarakat Muslim. Di samping karena besarnya arti pendidikan, kepentingan Islamisasi mendorong umat Islam melaksanakan pengajaran Islam kendati dalam sistem yang sederhana.

Pendidikan Islam mencapai bentuknya hingga sekarang ini merupakan hasil dari proses orang-orang Muslim menyikapi ajaran agamanya, karena Muslim dalam melakukan tindakannya senantiasa didasarkan pada acuan teks wahyu yang matluw (al-Quran) atau yang ghairu matluw (Hadis). ${ }^{1}$

Evolusi ini berlangsung cukup lama, mulai dari periode klasik (650 - 1250 M), bahkan saat nabi Muhammad saw. mengajarkan Islam kepada masyarakat Makkah dan Madinah, disusul masa khilafah Rasyidah, kemudian khilafah bani Umayyah, dan khilafah bani Abbasiyah. Proses ini terus berlanjut pada periode pertengahan $(1250$ - $1800 \mathrm{M})$ yang ditandai dengan kemunduran Islam dan akibat serangan Mongol serta muncul dan tenggelamnya tiga kerajaan besar, yakni Usmani di Turki, Safawi di Persia, Mughal di India, hingga periode modern; 1800 sampai sekarang. ${ }^{2}$

Dinamisasi proses pendidikan Islam tersebut berlangsung baik secara internal sebagai hasil ijtihad orang-orang Muslim dalam menyikapi kebutuhan umatnya, maupun eksternal sebagai akibat dari interaksi dengan umat dan budaya lain dimana Muslim

\footnotetext{
${ }^{1}$ Mengenai perbedaan antara wahyu yang matluw dengan wahyu yang ghairu matluw, baca Muhammad 'Ajaj Al-Khathib, Ushul al-Hadis bab Makanatu asSunnah fi al-Tasyri' (Libanon: Dar al-Fikr, Beirut).

${ }^{2}$ Badri Yatim, Sejarah Peradaban Islam (Jakarta: Raja Grafindo Persada, 2007), 6. Sementara Harun Nasution membagi sejarah Islam ke dalam tiga periode, yaitu klasik, pertengahan, dan modern dengan perincian dapat dibagi menjadi 5 masa, yaitu: 1) Masa hidupnya Nabi Muhammad saw. (571-632 M). 2) Masa hidupnya Khulafa ar-Rasyidin (632-661 M). 3) Masa hidupnya Daulah Umayyah di Damsyik (661-750 M). 4) Masa hidupnya Daulah Abbasiyah di Baghdad (750-1250 M). 5) Jatuhnya kekuasaan khalifah di Baghdad (tahun 1250 M sampai dengan sekarang). Lihat Harun Nasution, Pembaharuan Terhadap Islam: Sejarah Pemikiran dan Gerakan (Jakarta: Bulan Bintang, 1975), 11.
} 
berkomunikasi, seperti dengan bangsa yang ditaklukkan dalam ekspansinya, persentuhan dengan alam pemikiran Yunani, Persia, India, Cina, Mesir, maupun dengan kolonialisasi Barat, dan dunia global dewasa ini.

Meskipun terjadi perbedaan corak dan mode karena pengaruh dimensi tempat dan waktu, ${ }^{3}$ tetapi sumber pendidikan Islam esensinya tetap sama, yaitu al-Qur'an dan Hadis Nabi saw. Adanya variable ruang dan waktu yang terbentang antara nabi Muhammad saw. dengan keberadaan orang-orang Muslim pada zamannya melahirkan buah karya peradaban Islam yang beragam (seperti Fiqih, ilmu Kalam, Filsafat, Tasawuf, Kebudayaan, Teknologi, dan lain-lain) sebagai hasil dari kreativitas orang-orang Muslim membaca Islam dan menafsirkannya. Perambahan dan pengembangan peradaban Islam tersebut tidak lepas dari peranan pendidikan Islam sejak masa awalnya sampai sekarang.

Pertumbuhan dan perkembangan pendidikan Islam di atas bisa dirujuk dari masa Rasulullah saw. memulai pendidikan Islam dalam bentuknya yang paling awal sampai pada masanya Islam memberikan kontribusi yang sangat besar terhadap peradaban dunia, dan telah memberikan pengaruh yang sangat luas dalam rentang waktu berabad-abad dalam wilayah yang sangat luas, terutama pada masa kejayaan Islam di Baghdad dan Andalusia, dan dinasti-dinasti lain yang tumbuh seiring dengan melemahnya kekhalifahan Abbasiyah.

Pendidikan Islam pada masa Rasulullah saw. dan Khulafa Rasyidun, bahkan sampai akhir masa dinasti Umayyah, pendidikan Islam masih menyatu dengan dakwah Islam, belum ada pemisahan yang subtantif antar keduanya, kesemuanya berfokus pada pembebasan umat manusia dari pola kehidupan Jahiliyah menuju pola hidup yang tercerahkan. ${ }^{4}$

Menurut Syalaby, pendidikan Islam pada masa awalnya diselenggarakan di beberapa tempat yang berbeda-beda, seperti di

${ }^{3}$ Muhammad Tholhah Hasan, Dinamika Pemikiran tentang Pendidikan Islam (Jakarta: Lantabora Press, 2006), ix.

${ }^{4}$ Ibid., 55.

Jurnal Pendidikan Agama Islam

Volume 03, Nomor 01, Mei 2015

Hal $60-80$ 
rumah-rumah para ulama, di toko-toko buku, di masjid-masjid, dan lain-lain (seperti Baitul Hikmah masa Abbasiyah, Darul Hikmah Mesir, Kuttab [lembaga pendidikan dasar], perpustakaan [riset], Ruwaq, Zawiyah [latihan spiritual di masjid], Ribath [semacam Zawiyah namun lebih khusus aliran tertentu - tarekat - semacam pesantren], Baidiyah [sanggar pengajaran sastra, terutama sastra Arab kuno], Saloon [sanggar seni], Majlis [semacam seminariseminari, ulama melakukan diskusi spesialisasi, seperti majlis li alhadits, majlis li al-tarikh], Bimaristan [teaching hospital, uji coba praktik kedokteran], Observatorium), dengan bidang studi yang berbeda-beda juga, tetapi yang paling dasar adalah belajar membaca al-Qur'an, menulis dan pengetahuan dasar tentang agama dan akhlak Islam. ${ }^{5}$

Pada tahun 459/1067, merupakan awal penyelenggaraan pendidikan Islam di tempat khusus, yaitu Madrasah Nidhomiyah, ${ }^{6}$

${ }^{5}$ Ahmad Syalaby, Tarikh at-Tarbiyah al-Islamiyah, 43, 116-118; Ahmad Amin, Dhuha al-Islam, II, 49-50.

${ }^{6}$ Nama tersebut dinisbahkan kepada pendiriya, Perdana Menteri daulat Bani Saljuq, Nidhomu al-Mulk. Dalam penelitian-penelitian lain ditemukan bukti bahwa madrasah yang pertama didirikan bukanlah madrasah Nidhomiyah di Baghdad, tetapi jauh sebelum tahun $459 \mathrm{H}$. di Nisabur telah berdiri madrasah Al-Baihaqiyah, dan pendirinya adalah Abul Hasan 'Ali Al-Baihaqy (w. $414 \mathrm{H}$ ). lihat Al-Maqrizy, Al-Mawaidh wa al-I'tibar, 380. Pendapat tersebut juga didukung oleh penulis-penulis lain, seperti Naji Ma'ruf dalam bukunya "Madaris Makah" yang mengungkapkan, bahwa selama 2 abad sebelum madrasah Nidhomiyah di Baghdad berdiri, sudah ada madrasah di Transoksania dan Khurasan. Sebagai bukti, dia mengemukakan data dari Tarikh al-Bukhari yang menjelaskan, bahwa Ismail bin As'ad (w. 295 H) mempunyai madrasah yang dikunjungi oleh para siswa untuk melanjutkan pelajaran mereka. Dari hasil penelitian Richard W. Bulliet ditulis dalam The Patricians of Nisapur (Cambridge: Mass Havard University Press, 1972) mengungkapkan, bahwa di Nisabur terdapat sebanyak 39 madrasah, pada 2 abad sebelum berdirinya madrasah Nidhomiyah di Baghdad, dan madrasah yang tertua adalah Miyan Dahiya yang mengkhususkan pengajaran fiqih madzhab Maliki. Pada umumnya madrasah-madrasah tersebut mengajarkan satu madzhab fiqih saja dan sebagian besar madzhab Syafi'i. Rinciannya, dari 39 madrasah tersebut hanya satu madrasah yang mengajarkan fiqih Maliki, empat madrasah mengajarkan fiqih Hanafi, dan yang lain mengajarkan fiqih Syafi'i. Baca Depag R1, Sejarah Madrasah (Jakarta: Depag RI, 2004), 37. 
yang mempunyai ciri-ciri disamping tempat belajar yang terbagi menjadi kelas-kelas, ada guru-guru khusus yang bertugas, ada kurikulum yang ditetapkan, ada batasan waktu yang harus ditempuh. Salah seorang guru yang pernah mengajar di madrasah Nidhomiyah tersebut adalah Imam Abu Hamid Al-Ghazali.7 Setelah itu dibuka madrasah-madrasah lain di beberapa kota bahkan sampai ke desa-desa. ${ }^{8}$

\section{Pemetaan Kekuasaan Politik Majapahit}

Dari model pendidikan Islam yang ada di negara-negara yang berpenduduk Muslim, terlihat bahwa pendidikan Islam dalam proses dan perkembangannya tidak bisa dilepaskan dari dinamika politik, ekonomi, dan kondisi sosial-budaya suatu negara dimana umat Islam berada. Hal yang sedemikian itu dialami pula pada masa kerajaan Majapahit. Majapahit disebut-sebut sebagai sebuah kerajaan besar, menguasai seluruh wilayah yang sekarang bernama Indonesia, bahkan kekuasaannya sampai ke beberapa wilayah manca negara; Semenanjung Tanah Melayu, Singapura, Brunei.

Tercatat dalam Nagarakretagama, Pararaton dan berita dari Cina zaman dinasti Ming, bahwa sejak tahun 1331, wilayah Majapahit diperluas berkat penundukan Sadeng di tepi Sungai Badadung dan Keta di pantai utara, dekat Panarukan, seperti diberitakan dalam Nagarakretagama pupuh 48/2, 49/3 dan dalam

\footnotetext{
7 Ahmad Syalaby, Tarikh at-Tarbiyah al-Islamiyah, 43, 116-118; Ahmad Amin, Dhuha al-Islam, II, 49-50.

8 Pemakaian istilah madrasah secara definitif baru muncul pada abad ke- 11 . Universitas pada jenjang tertentu dalam pendidikan disebut juga madrasah. Penjelasan istilah madrasah merupakan transformasi dari masjid ke madrasah. Ada beberapa teori yang berkembang seputar proses transformasi tersebut antara lain George Makdis (1981) menjelaskan bahwa madrasah merupakan transformasi insitusi pendidikan Islam dari masjid ke madrasah terjadi secara tidak langsung melalui tiga tahap: Pertama, tahap masjid. Kedua, tahap masjidkhan; dan Ketiga, tahap madrasah. Lihat Ahmad Ibrahim Syarif, Daulat al-Rasul fi al-Madinat (Quwait: Dar al-Bayan, 1972), 76.
} 
Pararaton. Pada waktu itu, wilayah kerajaan meliputi seluruh Jawa Timur dan Pulau Madura. ${ }^{9}$

Baru setelah seluruh daerah Jawa Timur dikuasai penuh, Majapahit mulai menjangkau pulau-pulau di luar Jawa, yang disebut Nusantara. Menurut Pararaton, politik perluasan wilayah ke Nusantara bertalian dengan program politik Gadjah Mada yang diangkat sebagai Patih Amangkubumi pada tahun 1334. Untuk menyukseskan program politik itu, pembesar-pembesar Majapahit yang tidak menyetujui, disingkirkan oleh Gadjah Mada. ${ }^{10}$ Program politik tersebut baru dijalankan secara efektif mulai tahun 1343 dengan penundukan Bali, pulau yang paling dekat dengan Jawa.

Penundukan Suwarnabhumi terjadi sekitar tahun 1350; keruntuhannya mengakibatkan daerah-daerah bawahannya di Sumatera dan Semenanjung Tanah Melayu jatuh ke dalam wilayah kekuasaan Majapahit. Dua belas negara bawahan Suwarnabhumi: 1 . Pahang; 2. Trengganu; 3. Langkasuka; 4. Kelantan; 5. Woloan; 6. Cerating; 7. Paka; 8. Tembeling; 9. Grahi; 10. Palembang; 11. Muara Kampe; 12. Lamuri, hampir semuanya disebut dalam daftar daerahdaerah bawahan Majapahit dalam Nagarakretagama pupuh 13 dan 14. Daftar itu menyebut juga nama-nama daerah bawahan lainnya. ${ }^{11}$

${ }^{9}$ Piagam Camunda, 1332, menguraikan bahwa Tribhuwana Tungga Dewi menguasai seluruh dwi pantara. Istilah dwi pantara ini kiranya harus ditafsirkan sebagai hyperbol, karena pada waktu itu kekuasaan Majapahit hanya terbatas sampai Pulau Jawa dan Madura saja, tidak sama dengan istilah Nusantara dalam program politik Gajah Mada pada tahun 1334.

${ }^{10}$ Pada waktu itu para menteri sedang lengkap duduk menghadap di balai penghadapan. Kembar memperolok-olok Gajah Mada dengan menyebut kesalahan-kesalahan dan kekurangan-kekurangannya, dan menumpahkan telempak, Ra banyak ikut serta menambah mengemukakan celaan-celaan. Jabung Terewes, Lembu Peteng tertawa. lalu Gajah Mada turun mengadukan soal itu ke hadapan batara di Koripan, baginda marah, kemarahan dan penghinaan ini disampaikan kepada Arya Tadah. Dosa Kembar telah banyak, Warak dilenyapkan, tak dikatakan pada Kembar, mereka mati semua (Pararaton, IX).

${ }_{11}$ Di daerah-daerah ini tidak ditemukan piagam sebagai bukti adanya kekuasaan Majapahit. Hikayat-hikayat daerah, yang ditulis kemudian, menyinggung adanya hubungan antara pelbagai daerah dan Majapahit dalam 
Rupanya, Palembang dijadikan batu loncatan bagi tentara Majapahit untuk menundukkan daerah-daerah lainnya di sebelah Barat Pulau Jawa.

Daerah-daerah di luar Jawa yang dikuasai Majapahit pada pertengahan abad ke-14 seperti diberitakan oleh Nagarakretagama pupuh 13 dan 14 itu, seperti berikut:

1. Di Sumatera: Jambi, Palembang, Dharmasraya, Kandis, Kahwas, Siak, Rokan, Mandailing, Panai, Kampe, Haru, Temiang, Parlak, Samudra, Lamuri, Barus, Batan, Lampung.

2. Di Kalimantan (Tanjung Pura): Kapuas, Katingan, Sampit, Kota Lingga, Kota Waringin, Sambas, Lawai, Kandangan, Singkawang, Tirem, Landa, Sedu, Barune, Sukadana, Seludung, Solot, Pasir, Barito, Sawaku, Tabalung, Tanjung Kutei, Malano.

3. Di Semenanjung Tanah Melayu (Hujung Medini): Pahang, Langkasuka, Kelantan, Saiwang, Nagor, Paka, Muar, Dungun, Tumasik, Kelang, Kedah, Jerai. ${ }^{12}$

4. Sebelah Timur Jawa: Bali, Badahulu, Lo Gajah, Gurun, Sukun, Taliwung, Dompo, Sapi, Gunung Api, Seram, Hutan Kadali, Sasak, Bantayan, Luwuk, Makasar, Buton, Banggawi, Kunir Galian, Salayar, Sumba, Muar (Saparua), Solor, Bima, Wandan (Banda), Ambon atau Maluku, Wanin, Seran, Timor. ${ }^{13}$

Dengan wilayah yang seluas itu, hubungan antara pemerintah pusat dan daerah, dan dengan negeri manca negara diatur sedemikian rupa.

bentuk dongeng, tidak sebagai catatan sejarah khusus. Dongeng-dongeng itu menunjukkan kekagumannya terhadap keagungan dan kekuasaan Majapahit.

${ }^{12}$ Kesah Raja Marong Mahawangsa (Kuala Lumpur: Pustaka Antara, 1965), 79. "Akan Pulau Serai itu pun juga hampirlah sangat bertemu dengan tanah daratan besar; maka akhimya itulah yang disebut oleh Gunong Jerai karena ia tersangat tinggi". Lihat juga Paul Wheatley, The Golden Khersonese, 261.

${ }^{13}$ Perlu dipahami bahwa pengertian daerah bawahan pada abad ke-14 berbeda dengan pengertian koloni dalam zaman modern. Persembahan upeti yang tidak banyak nilainya, oleh daerah tertentu kepada Majapahit, sudah dapat dianggap sebagai bukti pengakuan kekuasan Majapahit atas daerah yang bersangkutan dan karenanya daerah itu dianggap sebagai daerah bawahan. 
Di Jawa, ada sebelas negara bawahan, masing-masing diperintah oleh raja, dan lima daerah atau provinsi yang disebut mancanegara, masing-masing diperintah juru pangalasan atau dipati, yakni 1. Daha, diperintah oleh Bhre Daha alias Dyah Wiyat Sri Rajadewi; 2. Wengker, diperintah oleh Raja Wijayarajasa; 3. Matahun, diperintah oleh Raja Rajasawardhana; 4. Lasem, diperintah oleh Bhre Lasem; 5. Pajang, diperintah oleh Bhre Pajang; 6. Paguhan, diperintah oleh Raja Singawardhana; 7. Kahuripan, diperintah oleh Tribhawana Tanggadewi; 8. Singasari diperintah o1eh Raja Kertawardhana; 9. Mataram, diperintah oleh Bhre Mataram alias Wikramawardhana; 10. Wirabhumi, diperintah oleh Bhre Wirabhumi; 11. Pawanuhan, diperintah oleh putri Surawardhani. Semua yang memegang kuasa di negara bawahan adalah keluarga raja Majapahit.

Lima provinsi yang di manca negara disebut menurut kiblat, yakni utara, timur, selatah, barat, dan pusat, masing-masing diperintah oleh juru pangalasan yang bergelar Rakryan. Baik negara bawahan maupun daerah, mengambil pola pemerintahan pusat. Raja dan juru pangalasan adalah pembesar yang bertanggung jawab, namun pemerintahannya dikuasakan kepada patih; sama dengan pemerintahan pusat, dimana raja Majapahit adalah orang yang bertanggung jawab, tetapi pemerintahannya ada di tangan patih amangkubumi atau patih seluruh negara.

Nagarakretagama pupuh 10 menuturkan, jika Para patih datang ke Majapahit, mereka mengunjungi gedung kepatihan amangkubumi yang dipimpin oleh Gadjah Mada. Administrasi pemerintahan Majapahit dikuasakan kepada lima pembesar yang disebut sangpanca ri Wilwatikta, yakni patih seluruh negara, demung, kanuruhan, rangga, dan tumenggung. Mereka itulah yang banyak, dikunjungi oleh para pembesar negara bawahan dan daerah untuk urusan pemerintahan. Apa yang direncanakan di pusat, dilaksanakan di daerah oleh para pembesar tersebut.

Dari patih perintah turun ke wedana, semacam pembesar distrik; dari wedana turun ke akuwu, pembesar sekelompok desa, semacam lurah zaman sekarang; dari akuwu turun ke buyut 
pembesar desa; dari buyut turun kepada penghuni desa. Demikianlah tingkat organisasi pernerintahan di Majapahit dari pucuk pimpinan negara sampai rakyat pedesaan. Apa yang berlaku di Jawa diterapkan di Pulau Bali dengan patuh.

Tidak demikian halnya dengan pemerintahan di daerah seberang lautan. Pemerintahan daerah seberang lautan tidak mengalami perubahan apapun setelah menjadi daerah bawahan Majapahit. Dalam urusan negara, raja-raja atau pembesar daerah bawahan di seberang lautan berdaulat penuh. Kewajiban utama daerah bawahan terhadap pusat ialah menyerahkan upeti tahunan dan menghadap raja Majapahit pada waktu-waktu yang ditetapkan sebagai tanda kesetiaan dan pengakuan kekuasaan Majapahit. Pemerintah pusat tidak mencampuri urusan daerah. Nagarakretagama pupuh 16/5 menegaskan bahwa Majapahit memelihara angkatan laut yang sangat besar untuk melindungi daerah-daerah bawahan dan menghukum pembesar daerah yang membangkang terhadap pusat pemerintahan.

Dengan demikian kerajaan-kerajaan Islam di luar pulau Jawa yang telah eksis, seperti Samudra Pasai, kerajaan Melayu, tetap mengembangkan keislamannya, hingga pada masanya kelak, Islam mengambil peran yang sangat signifikan dalam melangsungkan kontinum sosial, budaya, ketika pemerintahan pusat melemah.

Nagarakertagama pupuh 15/1 mencatat nama beberapa negara tetangga yang konon mempunyai hubungan persahabatan dengan Majapahit, seperti Syangka, Ayudhapura, Dharmaanagari, Marutama, Rajapura, Campa, Kamboja, dan Yawana. Daftar nama itu hampir serupa dengan nama-nama yang disebut dalam pupuh 83/4 tentang tamu-tamu asing yang sering berkunjung ke Majapahit, terutama Para pedagang dan para pendeta. Banyak di antara para pendeta asing yang menetap di Majapahit berkat pelayanan yang baik. Mereka itu adalah penyebar kebudayaan India. Berkat usaha pendeta asing, Hinduisme di Majapahit bertambah kuat.

Mungkin sekali hubungan persahabatan itu terutama didasarkan atas kunjungan para pedagang dan pendeta, bukan karena adanya perwakilan asing timbal-balik di negara-negara yang 
bersangkutan seperti pada zaman sekarang. Tali persahabatan itu dimaksudkan sebagai usaha untuk menghindarkan serbuan tentara asing di daerah bawahan Majapahit di seberang lautan, terutama di Semenanjung Tanah Melayu, karena negara-negara tetangga itu kebanyakan berbatasan atau berdekatan dengan daerah bawahan tersebut. Lagi pula sebagian besar negara-negara tetangga itu menganut agama Hindu/Budha seperti Majapahit.

Hubungan antara Syangka (Sri Langka) dan Majapahit mungkin telah dimulai sejak pemerintahan Jayanagara (1309-1328), karena dalam piagam Sidateka, 1323, Raja Jayanagara menggunakan nama abhiseka Sri Sundarapandya Adiswara, sedangkan unsur Pandya mengingatkan dinasti Pandya di Sri Langka. Nama Sri Langka sudah dikenal pada abad ke-13 sebagai negara bawahan Sriwijaya. Mungkin sekali persahabatan antara Sri Langka dan Majapahit terutama akibat kunjungan pendeta-pendeta Budha dari Sri Langka ke Majapahit.

Hubungan antara Ayudhya ${ }^{14}$ dan Majapahit bertarikh di sekitar tahun 1350, setelah Ramadhipati berhasil menyerbu Sukhothai dan menawan Raja Lu Thai pada tahun 1349, kemudian mendirikan kerajaan Dwarawati. Negara baru Dwarawati yang berpusat di Ayudhya, banyak dipengaruhi oleh negara tetangganya, yang bercorak Hindu. Dari Khamer di sebelah timurnya, negara Dwarawati mengambil pola pernerintahan, kebudayaan, kesenian, dan sistem tulisan. Dari bangsa Mon dan Burma di sebelah baratnya, negara Dwarawati mengambil pola perundang-undangan yang bersumber pada perundang-undangan India, sedangkan dari Sri Langka, negara Dwarawati mengambil agama Budha.

Dharmanagari di pantai Timur Semenanjung Tanah Melayu, di bagian Selatan Siam, terkenal sebagai Ligor atau Nakhon Sithammarat, adalah kerajaan lama, yang dikenal sejak abad ke-8 seperti tercatat pada piagam Ligor. Pada waktu itu, menjadi negara bawahan Sriwijaya. Pada tahun 1350, ketika Ramadhipati mendirikan kerajaan Dwarawati yang berpusat di Ayudhya,

${ }^{14}$ G. Coedies, The Indianized States of Southeast Asia (1968), 222-223. 
Dharmanagari masih tetap berdiri sebagai negara merdeka dan mengadakan hubungan persahabatan dengan Majapahit.

Bahkan, ketika Rama Khamheng dari Sukhothai pada akhir abad ke-13 menegakkan kekuasaannya di wilayah Indo-Cina, Darmanagari tetap bertahan karena pada abad ke-14, seluruh Semenanjung Melayu dari Tumasik sampai Semang adalah daerah bawahan Majapahit, sedangkan daerah sebelah baratnya dikuasai oleh Ayudhya maka Dharmanagari hanya merupakan kerajaan kecil, terjepit antara Ayudhya dan daerah bawahan Majapahit.

Marutma, biasa disamakan dengan Martaban, ${ }^{15}$ terletak di delta Sungai Saluen, adalah kerajaan Mon. Sejak timbulnya kerajaan Burma dan Sukhotai pada abad ke-13, kerajaan Mon ini menjadi rebutan antara bangsa Burma dan bangsa Thai. Pada tahun 1201, kerajaan Mon berhasil dikuasai oleh Waeru dari suku Thai dengan bantuan Tarabaya, yang mengakibatkan kematian kedua belah pihak.

Martaban pada tahun 1318 jatuh dalam kekuasaan bangsa Thai di bawah pemerintahan Lai Thai, putra Rama Khamheng; diperintah bangsa Thai sampai tahun 1347, ketika bangsa Mon berhasil menggulingkan kekuasaan Lai Thai dan membebaskan negaranya dari kekuasaan bangsa Thai. Demikianlah pada pertengahan abad ke-14, kerajaan Mon di Martaban adalah negara merdeka dan menjadi tetangga daerah bawahan Majapahit di Semenanjung Melayu.

Kerajaan Campa dengan ibu kota Wijaya (Caban) di dekat Kota Binhdinh, terletak di pantai Timur Vietnam, adalah kerajaan lama, yang telah dikenal sejak permulaan abad Masehi. Campa mengadakan hubungan persahabatan dengan Jawa sejak zaman pemerintahan Raja Kertanagara, yang memerintah Singasari dari tahun 1270 sampai 1292. Konon, putri Tapasi dari Singasari kawin dengan Raja Jaya Singawarman III dari Campa. ${ }^{16}$

${ }^{15}$ Ibid., 219.

${ }^{16}$ Ibid., 217.

Jurnal Pendidikan Agama Islam

Volume 03, Nomor 01, Mei 2015

Hal 68-80 
Berkat perkawinan itu, Raja Jaya Singawarman melarang tentara Tartar, yang berlayar ke Jawa pada akhir tahun 1292, untuk menghukum Raja Kertanagara, mendarat di pantai Campa. Pada tahun 1314, Campa diperintah oleh Tran-Minh-tong, juga dikenal sebagai Che Nang dalam Sajarah Vietnam. Setelah gagal usahanya untuk merebut kembali daerah bagian utara dari kekuasaan bangsa Vietnam, dia diusir dari negaranya. Konon, Che Nang mengungsi ke Jawa pada tahun 1318. Pada waktu itu, Jayanagara yang memerintah kerajaan Majapahit.

Menurut Nagarakretagama, pada tahun 1365, kerajaan Campa mempunyai hubungan persahabatan dengan Majapahit. Pada waktu itu, Campa diperintah oleh Che Bong Nga, orang besar di Campa berkat kejayaannya dalam peperangannya melawan Dai Viet dari tahun 1361 sampai 1390. Masa pemerintahannya bertepatan dengan masa pemerintahan Dyah Hayam Wuruk di Majapahit, yakni dari tahun 1351 sampai 1389. Baik jalannya sejarah maupun masa keruntuhannya, kerajaan Campa hampir mirip dengan kerajaan Majapahit.

Che bong Nga digantikan oleh Ngaut Klaung Wijaya yang memerintah Campa dari tahun 1400 sampai 1441 dan mengambil nama abhiseka Indrawarman pada tahun 1422. Dia berjaya menyelamatkan negaranya dari ancaman Dai Viet, namun sepeninggalnya, timbullah perang saudara. Dalam masa tiga puluh tahun semenjak matinya Indrawarman, Campa diperintah oleh lima orang raja dari pelbagai dinasti, ganti berganti melalui peperangan, yang melemahkan kedudukan negara, sehingga ketika pada tahun 1471 diserang oleh bangsa Vietnam, kerajaan Campa runtuh dan sejak itu diduduki oleh bangsa Vietnam, dan tidak pernah bangun lagi.

Serat Kanda dan Babad Tanah Jawi memberitakan bahwa pada permulaan abad ke-15, Raja Brawijaya dari Majapahit kawin dengan putri Campa, seorang Muslim, yang juga bergelar putri Dwarawati. Karena putri Campa itu meninggal pada tahun 1448 
seperti tercatat pada batu nisannya di Trawulan ${ }^{17}$ maka dia meninggalkan Campa kira-kira pada zaman pemerintahan Indrawarman. Tetapi, tak ada tanda-tanda yang menunjukkan adanya agama Islam di Campa sebelum tahun 1471, sehingga berita tentang putri Campa di atas tidak cocok dengan epigrafi Campa, sehingga merupakan persoalan yang tidak gampang pemecahannya.

Sebaliknya, pengumuman Kaisar T'ai-tsu, pada tahun 1370, yang mendirikan dinasti Ming sejak jatuhnya dinasti Yuan pada tahun 1368, jelas menyatakan bahwa pada tahun 1370 Campa mengadakan hubungan persahabatan dengan Cina. Hubungan persahabatan meningkat pada permulaan abad ke-15 dalam pemerintahan Kaisar Yung-lo berkat aktivitas duta keliling Cheng Ho. Campa merupakan pelabuhan penting dan dijadikan pangkalan untuk melancarkan aktivitas Cheng Ho ke daerah-daerah di Asia Tenggara. Kiranya persoalan putri Campa perlu dihubungkan dengan aktivitas duta keliling Cheng Ho, yang jelas seorang pemeluk agama Islam.

Masa kerajaan Majapahit (1923-1478)18 dalam konfigurasi kekhalifahan besar di dunia Islam adalah sezaman atau berada pada masa kekhalifaan Islam di Andalusia (711-1492), Mamalik di Mesir (1250-1517), Safawi di Iran (1252-1736), Mughol di India (14821858), dan Utsmani di Turki (1290-1924). Sementara itu kerajaankerajaan Islam yang berada di Nusantra dan sezaman dengan masa Majapahit adalah Samudra Pasai (1207-1524). ${ }^{19}$

Hal tersebut penting dikemukakan, karena erat kaitannya dengan aspek dan variabel masuknya Islam ke Majapahit (Jawa) dan pola pendidikan Islam yang akan dibahas nanti. Karena disinyalir komunitas Islam telah berada di dalam lingkar kekuasaan kerajaan

${ }^{17}$ J. L. A. Brandes, Pararaton, 197.

18 Ada yang menyebut berakhirnya kerajaan Majapahit pada masa prabu Girindra Wardhana (1474-1527), dan memindahkan pusat kerajaan dari Trawulan ke Keling, dan oleh banyak ahli kurang diperhitungkan, karena "pusaka kerajaan" tidak diboyong ke Keling tetapi diboyong ke Demak.

19 A. Hasyimi dalam Marwan Saridjo, dkk, Sejarah Pondok Pesantren di Indonesia (Jakarta: Dharma Bhakti, 1980), 19. 
Majapahit pada akhir abad ke-13, ditandai dengan banyaknya makam Islam di Tralaya (sebelah selatan bekas istana Majapahit) nisan tertua bertahun 1376 dan nisan termuda 1611.20

Meski begitu, sangat sedikit sekali ilmuwan atau sumbersumber lain yang membicarakan secara khusus pendidikan Islam pada masa Majapahit. Bagaimana pendidikan tersebut memproduk kader ulama dan kader politisi dalam menjaga keberlangsungan Islam dan merubah karakter kawula Majapahit dari Hindu-Budha dan memberi nilai Islam.

Mengingat masa akhir kerajaan Majapahit merupakan titik balik dari kerajaan-kerajaan di Nusantara yang tergabung dalam satu hegemoni panji Majapahit menjadi kerajaan-kerajaan kecil yang berdiri sendiri-sendiri, demikian pula masa akhir kerajaan Majapahit merupan titik balik dari kerajaan-kerajaan di Nusantara yang banyak bercorak Hindu-Budha menjadi kerajaan-kerajaan bercorak Islam.

\section{Syekh Jumadil Kubro sebagai Ulama Peletak Islamisasi Majapahit}

Terdapat hal yang menarik dari sebuah sarasehan dalam peringatan haul ke 632 Syekh Jumadil Kubro yang diselenggarakan oleh Dinas Pariwisata dan kebudayaan Kabupaten Mojokerto. Dari sejumlah pakar, baik dari ahli arkeologi, sejarahwan maupun dari kalangan ulama yang diundang ada benang merah dalam menyepakati sosok Syekh Jumadil Kubro. Syekh Jumadil Kubro adalah tokoh nyata dan benar adanya dan bukan tokoh fiktif. Namun bagaimana meninggalnya dan di mana Syekh Jumadil Kubro dimakamkan, masih diperdebatkan.

Ada anggapan bahwa makam tujuh yang nisannya bertuliskan arab di Tralaya salah satunya adalah Syek Jumadil Kubro. Namun anggapan tersebut terbantahkan tatkala merujuk penelitian S.T. Damais -seorang arkeolog Belanda. Dari penelitiannya, dia menyimpulkan bahwa tujuh makam di Tralaya

${ }^{20}$ Louis-Charles Damais, Epigrafi dan Sejarah Nusantara. 
yang bertuliskan Arab tersebut adalah seorang muslim. Namun tidak ada satu nisanpun yang bertuliskan nama seseorang. ${ }^{21}$ Artinya tidak ada bukti kongkret bahwa salah satu makam tujuh tersebut adalah Syekh Jumadil Kubro.

Meski demikian, yang sangat menarik justru adalah posisi makam muslim yang ditempatkan dalam makam kerajaan Majapahit. Padahal Tralaya, menurut bahasa kawi berasal dari kata Ksetralaya (lapangan mayat), merupakan makam khusus untuk penguburan kerabat raja, atau orang-orang dalam istana. Menurut Agus Sunyoto makam Tralaya merupakan makam khusus penganut aliran Yogatantra. ${ }^{22}$ Aliran Yoga-tantra merupakan sekte dari Hindu yang banyak diikuti oleh kerabat Istana. Baik Damais dan Sunyoto sepakat menyatakan bahwa ketujuh makam muslim tersebut adalah kerabat raja, atau orang yang sudah mendapatkan kehormatan dari raja.

Dengan demikian dapat disimpulkan bahwa makam Syekh Jumadil Kubro yang diyakini oleh masyarakat ada di Tralaya seperti sekarang ini, tidak memiliki dasar otentik. Tidak ada satupun bukti bahwa makam Tralaya terdapat nama Syekh Jumadil Kubro. Karena jika kita menelaah lagi, makam Syekh Jumadil Kubro terdapat di berbagai tempat. Ada yang meyakini Syekh Jumadil Kubro dimakamkan di Gresik, ada pula yang meyakini di Mantingan, dan ada pula yang meyakini makamnya di desa Turgu, Gunung Kawastu Yogyakarta, ada pula yang meyakini di Bugis. Bahkan ada yang meyakini di Madinah. Semuanya mengklaim kebenaran masingmasing.

Walaupun begitu, ada satu hal yang banyak disepakati oleh para ilmuwan bahwa Syekh Jumadil Kubro adalah ulama awal pra-

21 Di sana terdapat 44 nisan kuno dari 36 makam. Tidak ada goresan yang menyebutkan nama di nisan tersebut. Tulisan Arab yang memenuhi batu nisan di sana lebih banyak melantunkan dakwah, misalnya kutipan Surat Ar-Rahman Ayat 26-27. Lainnya adalah bacaan doa dan kalimat thayibah, kalimat tauhid, kutipan ayat-ayat al-Quran, doa permohonan ampun dan pengagungan Tuhan dengan tanda-tanda sufistik.

22 Agus Sunyoto, Mengkaji dan Merefleksikan Dakwah Syekh Jumadil Kubro (Mojokerto: Makalah pada Sarasehan Dinas Pariwisata Kab. Mojokerto, 2008), 2.

Jurnal Pendidikan Agama Islam Volume 03, Nomor 01, Mei 2015 Hal 72-80 
Wali songo bahkan menurut Babad Cirebon merupakan buyut dari semua wali songo.23 Oleh karenanya sangatlah tepat jika kita meletakkan Syekh Jumadil Kubro-lah peletak dakwah Islamisasi di jagat Nusantara ini. Syekh Jumadil Kubro-lah peletak model pendidikan Islam sebagai transformasi nilai kepada masyarakat jawa khususnya Majapahit.

Dengan kesepakatan demikian penulis menyimpulkan bahwa Syekh Jumadil Kubro adalah tokoh Islam awal Masa Majapahit. ${ }^{24}$ Karena dari catatan Van Bruinessen menceritakan ada cerita dari mulut ke mulut di desa-desa yang terletak di lereng Gunung Merapi, sebelah utara Yogyakarta, Syekh Jumadil Kubro dipercaya sebagai wali Muslim Jawa yang paling tua, yang berasal dari Majapahit dan hidup sebagai pertapa di hutan gunung tersebut. ${ }^{25}$ Begitupun dengan beberapa catatan dari Gresik menceritakan bahwa Syekh Jumadil Kubro merupakan pembimbing para wali.

Diceritakan Raden Rahmat yang kemudian menjadi sunan Ampel, lahir dari perkawinan seorang ulama Arab dengan putri Campa, pertama-tama datang ke Palembang dan dari sana meneruskan perjalanan ke Majapahit. Dia mendarat di Gresik, dimana dia mengunjungi Syaikh Molana Jumadil Kubro, seorang abid yang menetap di Gunung Jali. ${ }^{26}$ Bukti lain, di dalam serat Kandha, ada disebutkan keberadaan empat tokoh suci umat Islam di jaman kuno, yaitu Jumadil Kubro di Mantingan, Nyampo di Suku Dhomas, Dada Pethak di Gunung Bromo dan Maulana Ishak di Blambangan.

Sementara menurut cerita tutur di kalangan pengikut Syekh Siti Jenar, Syekh Jumadil Kubro adalah teman baik Syekh Siti Jenar

\footnotetext{
23 Al-Baqir dalam Martin Van Bruinessen, Kitab Kuning ( Bandung: Mizan, 1995), 237

${ }^{24}$ Menurut Zamakhsyari Dofier Islam memasuki arena kehidupan orang Jawa pada masa pertumbuhan dan perluasan Kerajaan Hindu Majapahit. Berkaitan dengan pernyataan Dofier dapat disimpulkan jika kita meyakini bahwa Syekh Jumadil Kubro adalah ulama awal peletak Islamisasi maka bisa jadi Syekh Jumadil Kubro-lah ulama yang berkiprah di dalam kekuasaan Majapahit. Zamakhsyari Dofier, Tradisi Pesantren ( Jakarta: LP3ES, 1982), 8.

${ }^{25}$ Van Bruinessen, Kitab Kuning...., 240.

${ }^{26}$ Ibid., 239.
} 
saat membawa tawar tanah-tanah angker bekas pemujaan aliran Yoga-tantra yang terkenal dengan kesaktiannya.. ${ }^{27}$ Dari beberapa bukti tersebut meskipun berbeda versi, membuktikan peran besar dan eksistensi Syekh Jumadil Kubro dalam menyumbangkan Islamisasi di tanah jawa.

\section{E. Model Pendidikan Islam Masa Majapahit}

Tidak ada bukti-bukti jelas untuk menggambarkan pendidikan Islam di Majapahit. Beberapa ilmuwan meyakini bahwa cikal bakal penelitian di Jawa adalah pesantren.28 Namun terdapat perbedaan dalam mengidentifikasi kapan pesantren awal itu didirikan. Dalam Babad Tanah Djawi, dijelaskan bahwa di Ampel telah mendirikan lembaga pendidikan Islam sebagai tempat ngelmu atau ngaos pemuda Islam. Zamakhsyari Dofier mengidentifikasi pesantren mulai berkembang pada abad ke-15.29

Dofier mengidentifikasi bahwa manuskrip-manuskrip keislaman kebanyakan ditulis dengan tulisan dari bahasa Jawa, baik

\footnotetext{
${ }^{27}$ Agus Sunyoto, Mengkaji..., 2.

${ }^{28}$ Mengenai arti kata pesantren, telah terjadi perbedaan pendapat di kalangan santri yang mendapat awalan "pe" dan akhiran "an" yang berarti tempat tinggal para santri. Sedangkan istilah santri berasal dari bahasa Tamil, yang berarti guru mengaji. Menurut Robson, kata santri berasal dari bahasa Tamil "sattiri" yang diartikan sebagai orang yang tinggal disebuah rumah miskin atau bangunan keagamaan secara umum. Walaupun kedua pendapat diatas terdapat perbedaan satu sama lain, masih bisa ditarik benang merah yang sama untuk menafsirkan arti kata "santri". Keduanya berpendapat bahwa santri berasal dari bahasa Tamil. Bila menengok pendapat pertama, bahwa santri guru mengaji, terdapat persamaan dengan fenomena santri, dimana santri adalah orang-orang yang memperdalam agama kemudian mengajarkannya kepada umat Islam dan orang-orang demikian oleh masyarakat Jawa dikenal dengan istilah "guru mengaji". Meski tidak sama redaksinya, pendapat Robson tentang santri bisa diterima karena rumusannya mengandung ciri-ciri yang berlaku bagi santri. Ketika memperdalam ilmu agama, para santri harus tinggal di asrama yang bangunannya merupakan bangunan keagamaan. Kalaupun disebutkan sebagai orang yang tinggal di rumah miskin, ada benarnya. Kehidupan santri dikenal sangat sederhana. Sampai tahun 60-an, pesantren dikenal dengan nama pondok, karena terbuat dari bambu, yang mana pada saat itu masih terdapat kesan kesederhanaan. Hanun Asroha, Sejarah Pendidikan Islam ( Jakarta: Depag, 1999), 145.

${ }^{29}$ Zamakhsyari Dofier, Tradisi Pesantren....., 23.
} 
yang isinya merupakan terjemahan karya asli dari bahasa Arab, maupun karya ulasan. ${ }^{30}$ Berbeda dengan Manfred, dia meyakini bahwa pesantren telah ada pada pertengahan abad ke-9. Dia mendasarkan bentuk Asrama yang mirip dengan tempat pendidikan Budha. Namun dia tidak menjelaskan lebih jauh bagaimana pesantren yang kemudian menjadi label khusus untuk orang yang menekuni agama Islam itu berdiri.

Dari pemaparan tersebut dapat diidentifikasi bahwa kehadiran Pesantren lebih akhir dari kehidupan Syekh Jumadil Kubro. Artinya masa Syekh Jumadil Kubro dalam kehidupan di Majapahit belum ada istilah pesantren. Belum ada bangunan pesantren sebagai tempat belajar agama Islam. Jadi pendidikan Islam di Masa Majaphit, bukan dalam bentuk pesantren. Kemungkinan besar pendidikan Islam dalam bentuk yang sangat sederhana.

Penulis lebih meyakini bahwa pengajaran Islam dilakukan di masjid-masjid. Karena masjid merupakan tempat vital di kalangan umat Islam. Di manapun ada komunitas Islam pasti akan berdiri sebuah bangunan Masjid. Apalagi jika telah terbentuk komunitas baru, pasti pendirian Masjid merupakan keharusan, selain sebagai tempat beribadah ia juga merupakan simbol akan keberadaan umat Islam. Hal yang sama jika mengamati keberadaan komunitas muslim di pusat Kerajaan Majapahit dengan terdapatnya makam Muslim di Tralaya, bukannya tidak mungkin bahwa di pusat Majapahit telah dibangun Masjid. ${ }^{31}$

Hal ini dikuatkan oleh Kidung Sunda, teks Jawa dari abad pertengahan menyebut istilah Masigit Agung, mirip istilah Masjid Agung. Kata masigit agung disebutkan berkaitan dengan keberangkatan rombongan Raja Sunda yang mengantar anak perempuannya untuk dipersunting oleh Raja Hayam Wuruk dari Majapahit. Sesampai di Bubat, dekat Surabaya, Raja Sunda tidak

\footnotetext{
${ }^{30}$ Ibid.

31 E. Badri Yunardi, Mesjid-mesjid Kuno di Gresik Jawa Timur dalam Rudy Harisyah, Sejarah Masjid-masjid Kuno di Indonesia (Jakarta: Depag, 1999), 7376.
} 
menjumpai sambutan kerajaan sebagaimana diharapkan. Kemudian raja Sunda mengirim patihnya ke Majapahit untuk menemui Gajah Mada. Dalam perjalanan Patih ke Majapahit, dia pertama kali tiba di Masigit Agung. 32

Dengan demikian, proses Islamisasi atau proses pengajaran Islam di Masa Majapahit kemungkinan besar banyak dilakukan lewat Masjid. Jika sebuah pendidikan atau pengajaran dilakukan di Masjid bentuk dari pengajarannya biasanya menggunakan bentuk halaqahhalaqah. ${ }^{33}$ Halaqah-halaqah -bentuk lingkaran, mirip orang berdiskusi dengan guru di tengah-tengah- sudah dilakukan pada masa-masa awal perkembangan Islam. ${ }^{34}$ Sejak masa Nabi, Masjid berfungsi sebagai tempat sosialisasi, tempat ibadah, tempat pengadilan dan lain sebagainya. Tetapi yang lebih penting adalah sebagai lembaga pendidikan.

Kemudian, kemungkinan besar pendidikan Islam di Masa Majapahit dilakukan pula lewat rumah-rumah ulama. Karena jika kita melihat sistem pendidikan awal Islam juga banyak dilakukan di rumah-rumah sebelum terbentuknya Masjid. Ketika masih di Mekkah, Rasulullah menggunakan rumah Al-Arqam sebagai tempat memberikan pelajaran bagi kaum muslimin. Di rumah-rumah ulama ini pulalah masa-masa penyebaran Islam, digunakan secara efektif untuk transformasi ilmu-ilmu agama kepada masyarakat luas.

Dengan demikian bisa dipastikan bahwa pendidikan masa Majapahit tidak jauh dari logika penyebaran masa awal Islam. Rumah ulama dan Masjid sebagai lembaga pendidikan pada tingkat sederhana menjadi sarana efektif pendidikan Islam kepada masyarakat Jawa sebelum terbentuknya pesantren sebagai lembaga pendidikan Islam yang lebih sempurna.

\footnotetext{
${ }^{32}$ Hanun Asroha, Pelembagaan Pesantren (Jakarta: Depag, 2004), 73

${ }^{33}$ Halaqah artinya lingkaran. Seorang guru biasanya duduk di atas lantai sambil menerangkan, membacakan karangannya, atau komentar orang lain terhadap suatu karya pemikiran. Murid-muridnya akan mendengarkan penjelasan guru dengan duduk di atas lantai, yang melingkari gurunya. Kadang-kadang sistem ini juga menggunakan kursi tidak duduk di lantai. Hanun Asroha, Sejarah Pendidikan Islam (Jakarta: Depag, 1999). 49

${ }^{34}$ Hanun Asroha, Sejarah Pendidikan Islam, 67.
} 
Adapun pelajaran yang disampaikan kepada masyarakat, kemungkinan besar masih berkutat pada ilmu agama yang mendasar. Hal ini didasarkan pendapat Raffles, meskipun secara general Jawa telah ter-Islam-kan namun sedikit sekali kelompokkelompok masyarakat yang betul-betul mengerti dan mengamalkan ajaran-ajaran Islam. Raffles menegasakan bahwa hanya beberapa orang saja yang sebenarnya memiliki pengetahuan yang cukup tentang Islam dan perilakunya sesuai dengan ajaran-ajaran Islam. Secara umum dapat disimpulkan bahwa sementara mereka percaya kepada Allah yang Maha Kuasa dan Nabi Muhammad sebagai utusannya dan mengerjakan beberapa perintah-perintah ibadah, tetapi mereka sebenarnya masih sedikit sekali mengetahui doktrindoktrin Islam. ${ }^{35}$

\section{F. Kesimpulan}

Jika melihat konversi besar-besaran penduduk Jawa kepada Islam, maka sah untuk menyatakan kehebatan dan kelihaian muballigh Muslim (baca: Syekh Jumadil Kubro) di dalam mengatur dakwah Islamnya. Bagaimana tidak, kekuatan Hindu-Majapahit yang begitu kokoh dengan didukung nama besar kerajaannya mampu "ditaklukan" dalam cengkraman aqidah Islam.

Agus Sunyoto dalam analisisnya menyatakan bahwa Hindu dan Budha yang berkembang di Majapahit ternyata hanya banyak dianut oleh keluarga kerajaan. Sedangkan arus grass root tetap melestarikan keyakinan mereka yakni ajaran Kapitayan. Di dalam ajaran Kapitayan ada kemiripan-kemiripan dengan ajaran Islam. Disinilah kearifan yang ditunjukkan ulama terdahulu. Mereka tidak memaksakan konsep Islam secara utuh, namun mereka dengan bijak ngemong kepada masyarakat dengan tetap membiarkan alur termterm yang sudah membudaya dan menjadi makanan sehari-hari mereka.

Istilah-istilah agama setempat yang masih menganut agama Kapitayan, tidak dibuang begitu saja. Tetapi tetap dipakai untuk

35 Zamakhasyari Dofier, Tradisi Pesantren....., 8.

Jurnal Pendidikan Agama Islam

Volume 03, Nomor 01, Mei 2015

Hal 77-80 
menyamakan dengan istilah ajaran Islam. Misalnya, dalam melakukan pemujaan kepada Allah swt. tidak menyebutkan shalat tetapi memakai istilah sembahyang. Begitupun dengan istilah tempat pemujaan, orang jawa menamakan tempat pemujaan kepada dewa disebut sanggar, namun oleh ulama diganti menjadi langgar. Istilah surga dikenalkan kepada masyarakat menggantikan istilah jannah. Istilah nar digantikan dengan istilah neraka, ${ }^{36}$ dan lain sebagainya. Sehingga, masyarakat awam dapat begitu mudah menerima ajaran Islam yang tidak jauh berbeda dengan istilahistilah agama yang lama.

Lebih dari itu, penulis berkeyakinan bahwa kedalaman spiritual dan akhlakul karimah dari sang muballigh Muslim juga merupakan hal yang menarik perhatian masyarakat grass root. Kepedulian, saling menyantuni, kesabaran, dan tata krama indah lainnya yang dianjurkan Islam menjadi tempat tersendiri dalam hati masyarakat yang konon menurut Agus Sunyoto orang Majapahit tidak mengenal demikian.

Orang Majapahit, berperingai kasar, sombong dan tidak mengenal mengalah. Prinsipnya menang atau mati. Namun anasiranasir kebrutalan perilaku tersebut lambat laun dihapuskan dengan kehadiran Islam. Penulis meyakini dengan bahasa hati-lah orang jawa mampu menerima Islam dan ber-Islam dengan sungguhsungguh meskipun dalam taraf yang masih sederhana. Sejarah telah mencatat kesuksesan gemilang Islamisasi Nusantara begitu cepat dan menyebar luas sehingga negara yang dihuni ini berpenduduk Muslim terbesar di dunia.

Membaca hal tersebut, hendaknya kita sadar, di dalam mendidik masyarakat tidak bisa dengan menggunakan bahasa kekerasan untuk mematuhi aturan agama. Atau dengan bahasa kekuasaan. Karena jika kita mendidik masyarakat dengan bahasa kekerasan atas nama agama atau bentuk-bentuk kekuasaan maka yang akan muncul selalu bentuk resistensi. Namun jika kita menggunakan sentuhan-sentuhan hati atau dalam bahasa lain

${ }^{36}$ Agus Sunyoto, Mengkaji..., 7.

Jurnal Pendidikan Agama Islam Volume 03, Nomor 01, Mei 2015 Hal 78-80 
gerakan kultural, maka masyarakat akan mudah menerima. Karena bahasa hati adalah bahasa fitrah. Bahasa hati adalah bahasa kesadaran universal yang diidealkan oleh semua manusia. Bahasa hati adalah bahasa revolusi kesadaran berakhlak dan bertauhid. 


\section{DAFTAR PUSTAKA}

Al-Khathib, Muhammad 'Ajaj, Ushul al-Hadis bab Makanatu as-Sunnah fi al-Tasyri' (Libanon: Dar al-Fikr, Beirut).

Asroha, Hanun, 1999, Sejarah Pendidikan Islam (Jakarta: Depag). 2004, Pelembagaan Pesantren (Jakarta: Depag).

Bruinessen, Martin Van, 1995, Kitab Kuning (Bandung: Mizan).

Bulliet, Richard W., 1972, The Patricians of Nisapur (Cambridge: Mass Havard University Press).

Depag R1, 2004, Sejarah Madrasah (Jakarta: Depag RI).

G. Coedies, 1968, The Indianized States of Southeast Asia.

Harisyah, Rudy, 1999, Sejarah Masjid-masjid Kuno di Indonesia (Jakarta: Depag).

Hasan, Muhammad Tholhah, 2006, Dinamika Pemikiran tentang Pendidikan Islam (Jakarta: Lantabora Press).

Kesah Raja Marong Mahawangsa, 1965 (Kuala Lumpur: Pustaka Antara).

Nasution, Harun, 1975, Pembaharuan Terhadap Islam: Sejarah Pemikiran dan Gerakan (Jakarta: Bulan Bintang).

Saridjo, Marwan, dkk, 1980, Sejarah Pondok Pesantren di Indonesia (Jakarta: Dharma Bhakti).

Sunyoto, Agus, 2008, Mengkaji dan Merefleksikan Dakwah Syekh Jumadil Kubro (Mojokerto: Makalah pada Sarasehan Dinas Pariwisata Kab. Mojokerto).

Syarif, Ahmad Ibrahim, 1972, Daulat al-Rasul fi al-Madinat (Quwait: Dar al-Bayan).

Yatim, Badri, 2007, Sejarah Peradaban Islam (Jakarta: Raja Grafindo Persada). 